\title{
ANALISIS SEKTOR UNGGULAN PEREKONOMIAN DI KABUPATEN/KOTA DENPASAR, BADUNG, GIANYAR, DAN TABANAN
}

\author{
Putu Indra Perdana Putra ${ }^{1}$ \\ I Putu Yadnya ${ }^{2}$ \\ ${ }^{1,2}$ Fakultas Ekonomi dan Bisnis Universitas Udayana (Unud), Bali, Indonesia \\ e-mail : Indraperdana17@yahoo.com
}

\begin{abstract}
ABSTRAK
Penentuan sektor unggulan daerah merupakan hal yang sangat penting sebagai dasar dalam perencanaan pembangunan dan peningkatan perekonomian suatu daerah. Tujuan penelitian ini adalah untuk mengetahui sektor-sektor yang menjadi sektor unggulan perekonomian di kabupaten/kota di wilayah Sarbagita, sehingga meneliti di Kabupaten/Kota di wilayah Sarbagita. Populasi dan sampel yang digunakan yaitu 17 sektor menurut lapangan usaha dalam PDRB tahun 2014-2016, dan metode penentuan sampelnya adalah sensus. Penelitian ini menggunakan teknik analisis data Tipologi Klassen, LQ, dan Overlay. Berdasarkan hasil penelitian yang menjadi sektor unggulan di wilayah Sarbagita yaitu sektor perdagangan besar dan eceran, sektor jasa keuangan dan asuransi, dan sektor jasa pendidikan. sektor penyediaan akomodasi dan makan minum, sektor informasi dan komunikasi, sektor industri pengolahan, serta sektor administrasi pemerintah, pertahanan, dan jaminan sosial wajib. Kedepannya masing-masing pemerintah daerah harus bisa menjaga stabilitas pertumbuhan dari sektor unggulan tersebut, karena sektor unggulan tersebut merupakan kekuatan dan daya saing daerah dalam meningkatkan perekonomian daerah.
\end{abstract}

Kata kunci: sektor unggulan, tipologi klassen, LQ, overlay

\begin{abstract}
The determination of the regional leading sector is very important as the basis in the development planning and improvement of the economy of a region. The purpose of this study is to determine the sectors that become the leading sector of the economy in the regencies / cities in the region Sarbagita, so researching in the regencies / cities in the region Sarbagita. The population and sample used are 17 sectors according to business field in GRDP 2014-2016, and the method of determining the sample is census. This research uses data analysis technique of Klassen Tipology, LQ, and Overlay. Based on the results of research that became the leading sectors in the Sarbagita region are the major trade and retail sectors, the financial services and insurance sector, and the education services sector. the sector of accommodation and drinking, the information and communications sector, the processing industry sector, as well as the government administration, defense and social security sectors. In the future each local government should be able to maintain the stability of growth of the leading sectors, because the superior sector is the strength and competitiveness of regions in improving the regional economy.
\end{abstract}

Keywords: leading sector, klassen tipology, LQ, overlay 
Putu Indra Perdana Putra, Analisis Sektor Unggulan...

\section{PENDAHULUAN}

Sistem pemerintahan di Indonesia mengalami perubahan pada saat era reformasi berlalu, yaitu dari sentralisasi ke desentralisasi atau yang sering disebut dengan otonomi daerah. Otonomi daerah merupakan suatu sistem baru yang memberikan kewenangan dari pemerintah pusat kepada pemerintah daerah untuk mengatur dan mengelola sumber-sumber yang ada di daerahnya. Menurut Erawati dan Mahaendra Yasa (2012), pelaksanaan otonomi daerah dibebankan pada pemerintah kabupaten/kota, sehingga pemerintah kabupaten/kota diharapkan mampu mandiri didalam menyelenggarakan pemerintahan, menentukan kebijakan pembangunan serta pendanaan. Kondisi seperti ini akan mampu meningkatkan kemampuan dalam menggali dan mengelola sumber-sumber potensi yang dimiliki daerah, sehingga ketergantungan pada pemerintah pusat akan terminimalisir.

Menurut Wulandari dan Ayuningsasi (2014), salah satu cara untuk mengukur kemampuan daerah untuk melaksanakan otonomi daerah adalah dengan memperhatikan besarnya jumlah Pendapatan Asli Daerah (PAD) yang dapat diperoleh oleh suatu daerah. PAD merupakan sumber pendapatan daerah yang mencerminkan tingkat kemandirian daerah, semakin besar PAD maka daerah tersebut semakin mandiri yang ditunjukkan oleh ketergantungan daerah terhadap pemerintah pusat yang semakin berkurang. Menurut Ayu dan Wiagustini (2016), pemerintah daerah dapat melakukan manajemen pendapatan secara optimal dengan cara mengenali sumber-sumber potensi ekonomi daerah yang mampu menghasilkan pendapatan dan membuat sumber-sumber pendapatan baru.

Wilayah metropolitan didefinisikan sebagai suatu wilayah dengan 
konsentrasi penduduk yang besar, dengan kesatuan ekonomi dan sosial yang terpadu, dan mencirikan aktivitas kota. Wilayah metropolitan memiliki sifat yang strategis, disamping peranannya sebagai pusat pertumbuhan ekonomi, pusat permukiman, pusat kegiatan sosial budaya, umumnya juga sebagai pusat pemerintahan serta aktivitas-aktivitas lainnya (Erawati, 2012).

Sarbagita adalah wilayah metropolitan di Provinsi Bali yang dibentuk berdasarkan Peraturan Presiden Nomor 45 Tahun 2011 yang kemudian diubah dengan Peraturan Presiden Nomor 51 Tahun 2014 dimana peraturan tersebut menjelaskan bahwa kawasan perkotaan Denpasar, Badung, Gianyar, dan Tabanan yang selanjutnya disebut Kawasan Perkotaan Sarbagita adalah satu kesatuan kawasan perkotaan yang terdiri atas Kota Denpasar dan Kawasan Perkotaan Kuta sebagai kawasan perkotaan inti, Kawasan Perkotaan Mangapura dan Kawasan Perkotaan Jimbaran di Kabupaten Badung, Kawasan Perkotaan Gianyar, Kawasan Perkotaan Sukawati dan Kawasan Perkotaan Ubud di Kabupaten Gianyar, dan Kawasan Perkotaan di Kabupaten Tabanan, sebagai kawasan perkotaan di sekitarnya, yang membentuk kawasan metropolitan.

Pembagian wilayah dalam satu kawasan merupakan upaya pemerintah untuk meningkatkan pertumbuhan ekonomi sekaligus pemerataan pembangunan wilayah. Setiap kawasan strategis memiliki satu daerah yang dijadikan sebagai pusat pertumbuhan ekonomi bagi daerah sendiri dan daerah sekitarnya. Perbedaan tingkat kemajuan ekonomi antardaerah yang berlebihan merupakan ciri-ciri dari adanya kesenjangan regional dan dapat dilihat dari perbandingan PDRB setiap kabupaten/kota dalam satu kawasan (Puspitawati, 2013). 
Tabel 1.

\section{Laju Pertumbuhan Produk Domestik Regional Bruto Perkabupaten/Kota} Provinsi Bali Menurut Harga Konstan (persen) Tahun 2014 - 2016

\begin{tabular}{ccccc}
\hline No. & Kabupaten/Kota & $\mathbf{2 0 1 4}$ & $\mathbf{2 0 1 5}$ & $\mathbf{2 0 1 6}$ \\
\hline 1. & Jembrana & 6,05 & 6,23 & 5,95 \\
2. & Tabanan & 6,53 & 6,24 & 6,12 \\
3. & Badung & 6,98 & 6,27 & 6,79 \\
4. & Gianyar & 6,80 & 6,34 & 6,30 \\
5. & Klungkung & 5,98 & 6,11 & 6,26 \\
6. & Bangli & 5,83 & 6,22 & 6,23 \\
7. & Karangasem & 6,01 & 6,00 & 5,92 \\
8. & Buleleng & 6,96 & 6,12 & 6,01 \\
9. & Denpasar & 7,00 & 6,21 & 6,50 \\
\hline
\end{tabular}

Sumber: BPS Provinsi Bali, 2017

Sarbagita merupakan wilayah yang bisa dibilang cukup besar kontribusinya terhadap PDRB Provinsi Bali. Dilihat dari laju pertumbuhan PDRB keempat kabupaten/kota di wilayah Sarbagita ini pada tahun 2014-2016 sebagian besar mampu mengimbangi laju pertumbuhan PDRB Provinsi Bali seperti pada Tabel 1. yaitu pada Kota Denpasar laju pertumbuhan PDRB tahun 2014 sebesar 7,00\%, tahun 2015 mengalami penurunan menjadi 6,21\%, dan tahun 2016 terjadi kenaikan menjadi 6,50\%, dari tahun 2014-2016 laju pertumbuhan PDRB Kota Denpasar berada diatas pertumbuhan PDRB Provinsi Bali. Pada Kabupaten Badung, laju pertumbuhan PDRB tahun 2014 sebesar 6,98\%, tahun 2015 terjadi penurunan menjadi 6,27\%, dan tahun 2016 terjadi kenaikan menjadi 6,79\%. Laju pertumbuhan PDRB Kabupaten Badung dari tahun 2014-2016 mampu berada diatas laju pertumbuhan PDRB Provinsi Bali. Laju pertumbuhan PDRB Kabupaten Gianyar pada tahun 2014 yaitu sebesar 6,80\%, dan pada tahun 20152016 terjadi penurunan menjadi $6,34 \%$ dan $6,30 \%$, walaupun mengalami penurunan, laju pertumbuhan PDRB Kabupaten Gianyar dari tahun 2014-2016 tetap mampu menyaingi laju pertumbuhan PDRB Provinsi Bali dan yang terakhir, 
laju pertumbuhan PDRB Kabupaten Tabanan pada tahun 2014-2016 yaitu sebesar $6,53 \%, 6,24 \%$, dan $6,12 \%$.

Melihat dari hal tersebut, dapat disimpulkan bahwa sebagian besar kabupaten/kota di wilayah Sarbagita memiliki laju pertumbuhan PDRB yang lebih besar dari PDRB Provinsi Bali, namun cenderung berfluktuasi, tetapi pada kabupaten Gianyar dan Tabanan mengalami penurunan dari tahun 2014-2016.

Tabel 2.

Produk Domestik Regional Bruto Perkabupaten/Kota di Wilayah Sarbagita (miliar rupiah) Atas Dasar Harga Konstan 2010 Menurut Lapangan Usaha, 2014-2016

\begin{tabular}{ccccc}
\hline & Kabupaten/Kota & $\mathbf{2 0 1 4}$ & $\mathbf{2 0 1 5}$ & $\mathbf{2 0 1 6}$ \\
\hline 1 & Denpasar & $26.778 .585,1$ & $28.442 .260,0$ & $30.291 .024,3$ \\
2 & Badung & $27.458 .060,1$ & $29.180 .479,4$ & $31.160 .584,6$ \\
3 & Gianyar & $14.269 .422,6$ & $15.174 .404,6$ & $16.129 .908,4$ \\
4 & Tabanan & $11.907 .999,4$ & $12.651 .348,6$ & $13.426 .017,7$ \\
\hline & Rata-rata & $\mathbf{2 0 . 1 0 3 . 5 1 6 , 8}$ & $\mathbf{2 1 . 3 6 2 . 1 2 3 , 2}$ & $\mathbf{2 2 . 7 5 1 . 8 8 3 , 7}$ \\
\hline
\end{tabular}

Sumber: BPS Kabupaten/Kota Denpasar, Badung, Gianyar, dan Tabanan, 2017

Kabupaten/Kota di wilayah Sarbagita bisa dikatakan penyumbang terbesar terhadap PDRB di Provinsi Bali jika dilihat dari perolehan PDRB tahun 20142016. Kabupaten Badung menduduki peringkat pertama dalam perolehan PDRB tertinggi, lalu disusul oleh kota Denpasar, kabupaten Gianyar dan terakhir kabupaten Tabanan. Dilihat dari tabel 2 terjadi perbedaan PDRB yang mencolok antara satu daerah dengan daerah lainnya di wilayah Sarbagita. Kabupaten/Kota yang berada diatas rata-rata PDRB wilayah Sarbagita dalam kurun waktu 20142016 hanya Kota Denpasar dan Kabupaten Badung, sedangkan Kabupaten Gianyar dan Tabanan masih berada di bawah rata-rata. Perbedaan PDRB tersebut mengindikasikan adanya ketidakmerataan yang menyebabkan terjadinya 
Putu Indra Perdana Putra, Analisis Sektor Unggulan...

ketimpangan atau kesenjangan antar kabupaten/kota di wilayah Sarbagita, maka dari itu diperlukan usaha untuk meningkatkan pertumbuhan ekonomi di daerah tersebut.

Menurut Mahmudi (2009:48), kemampuan untuk mengenali potensi pendapatan dan memanfaatkannya secara optimal bagi manajer publik merupakan suatu hal penting yang menunjukkan kapasitas entrepreneurship mereka dalam mengelola organisasi sektor publik yang dalam hal ini pemerintah daerah harus bisa mengenali sektor-sektor yang menjadi sektor unggulan di daerahnya masingmasing yang berada di wilayah Sarbagita serta nantinya mampu memanfaatkannya secara optimal sehingga akan terwujudnya pemerataan pembangunan daerah di wilayah Sarbagita tersebut.

Menurut Arsyad (2015), cara yang digunakan untuk mengukur pertumbuhan suatu perekonomian terkait dengan potensi ekonomi daerah adalah dengan menggunakan alat analisis Shift Share, Location Quotient (LQ), Model Rasio Pertumbuhan (MRP), Overlay, dan Tipologi Klassen. Pada penelitian ini menggunakan tiga alat analisis untuk menentukan sektor - sektor yang menjadi sektor unggulan yaitu, Tipologi Klassen, Location Quotient (LQ) dan Overlay.

Menurut Mahmudi (2009:52), analisis Tipologi Klassen merupakan teknik pengelompokan suatu sektor dengan melihat pertumbuhan dan kontribusi sektor tertentu terhadap total PDRB suatu daerah, dimana dalam analisis ini sektor-sektor perekonomian yang terdapat di suatu daerah akan diklasifikasikan menjadi empat katagori yaitu, sektor unggulan, sektor potensial, sektor berkembang, dan sektor terbelakang. 
Analisis Location Quotient (LQ) merupakan suatu teknik analisis yang digunakan untuk mengidentifikasi dan memisahkan suatu sektor perekonomian apakah termasuk kedalam sektor basis atau bukan basis (Mack dan David, 1996). Analisis LQ ini juga merupakan suatu pendekatan untuk mengukur kinerja basis ekonomi suatu daerah atau pengujian terhadap sektor-sektor ekonomi yang termasuk dalam katagori sektor unggulan (Ayu \& Wiagustini, 2016).

Menurut Sabar (2015), analisis Overlay digunakan untuk menentukan sektor unggulan dengan menggabungkan alat analisis dengan tujuan untuk menyaring hasil analisis yang paling baik. Metode ini menghasilkan penilaian terhadap sektor - sektor ekonomi dengan melihat nilai positif (+) dan negatif (-). Sektor yang jumlah nilai positif (+) paling banyak, maka sektor tersebut merupakan sektor unggulan dan sebaliknya jika suatu sektor tidak mempunyai nilai positif berarti sektor tersebut bukan merupakan sektor unggulan.

Penelitian-penelitian sebelumnya yang menganalisis tentang penentuan sektor unggulan atau potensi ekonomi daerah menggunakan berbagai alat analisis yang mampu menghasilkan hasil yang serupa, seperti yang dilakukan oleh Erawati dan Mahendra Yasa (2012) yang meneliti tentang Kabupaten Klungkung dengan menggunakan analisis Tipologi Klassen, Location Quotient (LQ), analisis MRP, analisis Overlay, dan Rasio Penduduk Pengerjaan. Hasil dari pembahasan dan analisis menunjukkan bahwa pola pertumbuhan ekonomi Kabupaten Klungkung dalam periode tahun 2008-2010 menurut Tipologi Klassen termasuk dalam klasifikasi daerah makmur yang sedang menurun (potensial tertinggal), sedangkan sektor-sektor potensial yang dapat dikembangkan di Kabupaten Klungkung dalam 
Putu Indra Perdana Putra, Analisis Sektor Unggulan...

periode tahun 2008-2010 yaitu sektor bangunan dan sektor jasa-jasa, dan dari sektor jasa-jasa, sub sektor yang lebih dominan menyumbang kontribusi yaitu dari jasa swasta.

Yusral dkk. (2015) meneliti Kota Jambi pada tahun 2015 dengan menggunakan empat alat analisis seperti Tipologi Klassen, Location Quotient (LQ), Shift Share, dan analisis Overlay. Berdasarkan gabungan dari tiga alat analisis menunjukkan bahwa sektor yang merupakan sektor unggulan dengan kriteria tergolong ke dalam sektor yang maju dan tumbuh dengan pesat (kuadran I), sektor basis (LQ>1) dan kompetitif (nilai P dan D positif), yaitu sektor Perdagangan, Hotel dan Restoran.

Dearlinasinaga (2015) meneliti tentang analisis penentuan sektor ekonomi unggulan terhadap pembentukan PDRB di Simalungun pada tahun 2005-2011 dengan alat analisis Tipologi Klassen dan LQ. Berdasarkan hasil analisis Tipologi Klassen, yang merupakan sektor unggulan di Simalungun adalah sektor jasa dan berdasarkan hasil analisis LQ yang merupakan sektor basis adalah sektor jasa.

Kesuma \& Suyana Utama (2015) meneliti tentang Kabupaten Klungkung tahun 2008-2012 dengan alat analisis LQ dan Shift Share. Berdasarkan hasil perhitungan LQ dan Shift Share, yang merupakan sektor unggulan di Kabupaten Klungkung adalah sektor pertanian, sektor pertambangan dan penggalian, sektor bangunan, dan sektor jasa-jasa.

Ayu dan Wiagustini (2016) meneliti tentang potensi ekonomi daerah Provinsi Bali dengan menggunakan analisis Tipologi Klassen. Hasil dari penelitian menunjukkan bahwa sektor unggulan yang sama di seluruh 
kabupaten/kota di Provinsi Bali pada tahun 2012-2015 adalah sektor konstruksi, sektor berkembang adalah jasa kesehatan dan kegiatan sosial; sektor potensial adalah sektor pertanian, kehutanan dan perikanan; dan sektor terbelakang adalah sektor pengadaan air, pengelolaan limbah, sampah dan daur ulang; sektor pengadaan listrik dan gas.

Berdasarkan fenomena yang dialami oleh 4 kabupaten/kota di wilayah Sarbagita maka rumusan masalah dari penelitian ini yaitu sektor - sektor apa saja yang menjadi sektor unggulan perekonomian di wilayah Sarbagita ?.Tujuan penelitian ini adalah untuk mengetahui sektor-sektor yang menjadi sektor unggulan perekonomian di wilayah Sarbagita. Manfaat teoritis penelitian ini nantinya diharapkan mampu menghasilkan bukti empiris tentang sektor - sektor yang menjadi sektor unggulan di wilayah Sarbagita. Bagi pemerintah daerah di wilayah Sarbagita yaitu sebagai masukkan, bahan pertimbangan, dan petunjuk untuk mengambil suatu keputusan maupun strategi yang akan dilakukan dalam rangka mengembangkan dan mengelola perekonomian daerahnya masing masing.

Landasan teori penelitian ini adalah otonomi daerah. Menurut UU No. 32 Tahun 2004 tentang Pemerintahan Daerah dan UU No. 33 Tahun 2004 tentang Perimbangan Keuangan antara Pemerintah Pusat dan Pemerintahan Daerah, Otonomi Daerah adalah hak, wewenang, dan kewajiban daerah otonom untuk mengatur dan mengurus sendiri urusan pemerintahan dan kepentingan masyarakat setempat sesuai dengan peraturan perundang - undangan. Menurut Erawati dan Mahaendra Yasa (2012), pelaksanaan otonomi daerah dibebankan pada 
Putu Indra Perdana Putra, Analisis Sektor Unggulan...

pemerintah kabupaten/kota, sehingga pemerintah kabupaten/kota diharapkan mampu mandiri didalam penyelenggarakan pemerintahan, menentukan kebijakan pembangunan serta pendanaan. Adanya otonomi daerah ini diharapkan dapat meningkatkan inovasi dan inisiatif dari pemerintah daerah untuk mengelola dan mengoptimalkan sumber daya dan kekayaan yang dimiliki oleh daerah tersebut yang nantinya bisa dimanfaatkan sebagai modal untuk pembangunan daerah (Sudewi dan Wirathi, 2013). Menurut Uhunmwangho dan Stanley (2013), target pelaksanaan otonomi daerah adalah pemerintah daerah kabupaten/kota mampu memaksimalkan potensi ekonomi daerah yang dimilikinya. Pengoptimalan potensi tersebut bertujuan untuk meningkatkan pendapatan daerah sehingga penyelenggaraan pembangunan daerah sesuai dengan kebutuhan masyarakat.

Landasan teori yang kedua adalah Pendapatan Asli Daerah. Menurut Undang-undang Nomor 33 Tahun 2004 tentang Perimbangan Keuangan antara Pemerintah Pusat dan Pemerintahan Daerah, Pendapatan Asli Daerah (PAD) adalah pendapatan yang diperoleh daerah yang dipungut berdasarkan Peraturan Daerah yang sesuai dengan peraturan perundang-undangan. PAD merupakan salah satu indikator dalam mengukur ketergantungan suatu daerah terhadap Pemerintah Pusat (Gitaningtyas, 2014).

Landasan teori ketiga penelitian ini yaitu sektor unggulan. Menurut Aswandi dan Kuncoro (2002), pengertian sektor unggulan adalah sektor atau kegiatan ekonomi yang mempunyai potensi, kinerja dan prospek yang lebih baik dibandingkan dengan sektor lainnya sehingga diharapkan mampu menggerakkan kegiatan usaha ekonomi turunan lainnya, dan pada akhirnya akan dapat tercipta 
kemandirian pembangunan wilayah suatu daerah. Menurut Ratnasari (2014), sektor unggulan dapat menjadi dasar pertimbangan perencanaan pembangunan daerah di masa yang akan datang. Sektor unggulan akan memberikan keuntungan kompetitif atau komparatif yang selanjutnya akan mendorong pengembangan ekspor barang maupun jasa pada suatu wilayah sehingga berdampak pada peningkatan pendapatan daerah.

Landasan teori keempat penelitian ini yaitu Produk Domestik Regional Bruto (PDRB). PDRB adalah suatu indikator ekonomi makro yang dapat memberikan suatu gambaran mengenai keadaan perekonomian suatu wilayah (Prishardoyo, 2008). Menurut Tarigan (dalam Erawati dan Mahaendra Yasa, 2012), PDRB dapat dibedakan atas dasar harga berlaku dan atas dasar harga konstan.

\section{METODE PENELITIAN}

Jenis penelitian ini dapat dikategorikan sebagai jenis penelitian deskriptif. Lokasi atau ruang lingkup dari penelitian ini terdiri dari 4 kabupaten/kota yaitu Denpasar, Badung, Gianyar, dan Tabanan. Tujuan dipilihnya keempat kabupaten/kota ini adalah untuk meningkatkan kinerja pemerintah daerah terkait dengan pengoptimalan pengelolaan sektor-sektor ekonomi yang dimilikinya mengingat juga keempat kabupaten/kota ini merupakan kawasan metropolitan di Provinsi Bali yang dimana memiliki kontribusi yang cukup tinggi terhadap PDRB Provinsi Bali. Objek pada penelitian ini adalah 17 sektor dalam PDRB dari 
Putu Indra Perdana Putra, Analisis Sektor Unggulan...

keempat kabupaten/kota di wilayah Sarbagita atas dasar harga konstan tahun 2010 menurut lapangan usaha tahun $2014-2016$.

Variabel-variabel yang digunakan dalam penelitian ini adalah sektor unggulan, PDRB, dan laju pertumbuhan PDRB. Populasi dari penelitian ini adalah seluruh sektor ekonomi berupa 17 sektor lapangan usaha yang terdapat dalam PDRB yang dihasilkan dari kabupaten/kota Denpasar, Badung, Gianyar, dan Tabanan dan Provinsi Bali pada periode tahun 2014-2016. Sampel yang dipergunakan yaitu keseluruhan dari popolasi sehingga metode penentuan sampelnya yaitu menggunakan metode sensus.

Metode pengumpulan data yang digunakan dalam penelitian ini adalah metode observasi nonparticipant dan jenis data yang digunakan terdiri dari data kualitatif dan kuantitatif. Data kualitatif dalam penelitian ini yaitu berupa artikel dari penelitian-penelitian sebelumnya dan profil dari keempat kabupaten/kota di wilayah Sarbagita, sedangkan data kuantitatif dalam penelitian ini yaitu terdiri dari (1) data PDRB Provinsi Bali dan dari masing-masing kabupaten/kota di wilayah Sarbagita atas dasar harga konstan tahun 2010 menurut lapangan usaha tahun 2014 - 2016; (2) data PDRB secara sektoral Provinsi Bali dan dari masingmasing kabupaten/kota di wilayah Sarbagita atas dasar harga konstan tahun 2010 menurut lapangan usaha tahun 2014-2016 dan (3) laju pertumbuhan PDRB dan laju pertumbuhan masing-masing sektor PDRB Provinsi Bali dan dari masingmasing kabupaten/kota di wilayah Sarbagita yang dimana data-data tersebut merupakan data sekunder yang diperoleh dari data PDRB Provinsi Bali, PDRB Kota Denpasar, PDRB Kabupaten Badung, PDRB Kabupaten Gianyar, dan PDRB 
Kabupaten Tabanan atas dasar harga konstan tahun 2010 menurut lapangan usaha tahun 2014-2016 yang didapat dari website Badan Pusat Statistik Provinsi Bali, website Badan Pusat Statistik Kota Denpasar, website Badan Pusat Statistik Kabupaten Badung, website Badan Pusat Statistik Kabupaten Gianyar, dan website Badan Pusat Statistik Kabupaten Tabanan. Teknik analisis yang digunakan yaitu Tipologi Klassen, Location Quotient (LQ), dan Overlay.

\section{HASIL DAN PEMBAHASAN}

Berdasarkan hasil analisis Tipologi Klassen di Kota Denpasar, sektor menempati Kuadran I (sektor unggulan) yaitu (1) sektor perdagangan besar dan eceran $\left(\hat{Y}_{\text {SEKTOR }}=\right.$ Rp. 2.714.491,67 juta, $r_{\text {SEKTOR }}=$ 7,56 persen $)$, (2) sektor jasa keuangan $\&$ asuransi $\left(\hat{Y}_{\text {SEKTOR }}=\right.$ Rp. 1.826.761,33 juta, $r_{S E K T O R}=8,04$ persen $)$, dan (3) sektor jasa pendidikan $\left(\hat{Y}_{\text {SEKTOR }}=\right.$ Rp. $3.246 .732,21$ juta, $r_{S E K T O R}=8,79$ persen).

Berdasarkan hasil perhitungan analisis LQ, sektor yang termasuk kedalam sektor basis (LQ>1) yaitu (1) sektor industri pengolahan dengan rata-rata nilai LQ sebesar 1,05, (2) sektor pengadaan listrik dan gas dengan rata-rata nilai LQ sebesar 2,38, (3) sektor pengadaan air, pengolahan sampah, limbah \& daur ulang dengan rata-rata nilai LQ sebesar 1,43, (4) sektor konstruksi dengan rata-rata nilai LQ sebesar 1,02, (5) sektor perdagangan besar dan eceran dengan rata-rata nilai LQ sebesar 1,09, (6) sektor penyediaan akomodasi dan makan minum dengan rata-rata nilai LQ sebesar 1,16, (7) sektor jasa keuangan dan asuransi dengan ratarata nilai LQ sebesar 1,47, (8) sektor real estat dengan rata-rata nilai LQ sebesar 
Putu Indra Perdana Putra, Analisis Sektor Unggulan...

1,03, (9) sektor jasa perusahaan dengan rata-rata nilai LQ sebesar 1,78, (10) sektor jasa pendidikan dengan rata-rata nilai LQ sebesar 2,15, dan (11) sektor jasa kesehatan dan kegiatan sosial dengan rata-rata nilai LQ sebesar 1,06

Tabel 3.

Sektor Unggulan di Kota Denpasar

\begin{tabular}{lccc}
\hline \multicolumn{1}{c}{ Sektor Unggulan } & \multicolumn{3}{c}{ Hasil Analisis } \\
\cline { 2 - 4 } & Tipologi Klassen & LQ & Overlay \\
\hline Perdagangan Besar dan Eceran & Kuadran I & 1,09 & ++ \\
Jasa Keuangan dan Asuransi & Kuadran I & 1,47 & ++ \\
Jasa Pendidikan & Kuadran I & 2,15 & ++ \\
\hline
\end{tabular}

Sumber: data diolah, 2018

Dilihat dari tabel 3 sektor perdagangan besar dan eceran adalah salah satu aktivitas produksi yang menjadi potensi ekonomi unggulan Kota Denpasar. Menurut Dinas Penanaman Modal dan Pelayanan Terpadu Kota Denpasar, pada tahun 2016 telah menerbitkan Surat Ijin Usaha Perdagangan (SIUP) sebanyak 1.161 unit, hal ini memberikan dampak positif terhadap kontribusi yang diberikan sektor perdagangan kepada PDRB Kota Denpasar (Denpasar dalam angka, 2017).

Berdasarkan hasil perhitungan dari analisis Tipologi Klassen, LQ dan Overlay sektor perdagangan besar dan eceran memenuhi katagori sektor unggulan yaitu pada analisis Tipologi Klassen besarnya rata-rata kontribusi sektor terhadap PDRB Kota Denpasar $\left(\hat{Y}_{\text {SEKTOR }}\right)$ sebesar Rp. 2.735.253,96 juta (Rp. 2.735.253,96 juta $>$ Rp. 1.676.703,32 juta) dan rata-rata laju pertumbuhan sektornya $\left(r_{S E K T O R}\right)$ sebesar 7,56 persen (7,56 persen > 6,56 persen), sedangkan pada analisis LQ besarnya nilai LQ pada sektor perdagangan besar dan eceran yaitu 1,09 (1,09>1) dan pada analisis overlay yang didasari oleh kombinasi dari hasil analisis Tipologi Klassen dan LQ sektor ini memiliki dua nilai positif (+). 
Sektor unggulan kedua yaitu sektor jasa keuangan dan asuransi. Berdasarkan hasil perhitungan dari analisis Tipologi Klassen, LQ dan Overlay sektor jasa keuangan dan asuransi memenuhi katagori sektor unggulan yaitu pada analisis Tipologi Klassen besarnya rata-rata kontribusi sektor terhadap PDRB Kota Denpasar $\left(\hat{Y}_{\text {SEKTOR }}\right)$ sebesar Rp. 1.826.761,33 juta (Rp. 1.826.761,33 juta > Rp. 1.676.703,32 juta) dan rata-rata laju pertumbuhan sektornya $\left(r_{S E K T O R}\right)$ sebesar 8,04 persen $(8,04$ persen $>6,56$ persen $)$, sedangkan pada analisis LQ besarnya nilai LQ pada sektor jasa keuangan dan asuransi yaitu $1,47(1,47>1)$ dan pada analisis overlay yang didasari oleh kombinasi dari hasil analisis Tipologi Klassen dan LQ sektor ini memiliki dua nilai positif $(+)$.

Sektor unggulan yang terakhir yaitu sektor jasa pendidikan, dimana sektor ini merupakan salah satu sektor yang berkontribusi besar terhadap PDRB Kota Denpasar. Pembangunan di bidang pendidikan menjadi suatu hal yang prioritaskan dalam upaya peningkatan kualitas Sumber Daya Manusia (SDM), sehingga sektor ini berkaitan dengan penyediaan sarana dan prasarana pendidikan. Berdasarkan data dari Dinas Pendidikan, Kepemudaan dan Olahraga Kota Denpasar tahun 2016, tercatat 232 unit SD, 66 unit SLTP, dan 70 unit SLTA (Denpasar dalam angka, 2017:64).

Menurut hasil perhitungan dari analisis Tipologi Klassen, LQ dan Overlay sektor jasa pendidikan memenuhi katagori sektor unggulan yaitu pada analisis Tipologi Klassen besarnya rata-rata kontribusi sektor terhadap PDRB Kota Denpasar $\left(\hat{Y}_{\text {SEKTOR }}\right.$ ) sebesar Rp. 3.246.732,21 juta (Rp. 3.246.732,21 juta > Rp.

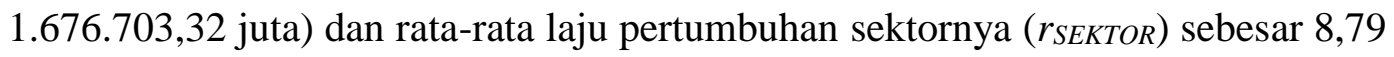


Putu Indra Perdana Putra, Analisis Sektor Unggulan...

persen $(8,79$ persen $>6,56$ persen $)$, sedangkan pada analisis LQ besarnya nilai LQ pada sektor jasa pendidikan yaitu $2,15(2,15>1)$ dan pada analisis overlay yang didasari oleh kombinasi dari hasil analisis Tipologi Klassen dan LQ sektor jasa pendidikan memiliki dua nilai positif $(+)$.

Berdasarkan hasil analisis Tipologi Klassen di Kabupaten Badung, sektor menempati Kuadran I (sektor unggulan) yaitu (1) sektor perdagangan besar dan eceran $\left(\hat{Y}_{\text {SEKTOR }}=\right.$ Rp. 2.223.497,33 juta, $r_{\text {SEKTOR }}=7,39$ persen $)$, (2) sektor penyediaan akomodasi dan makan minum $\left(\hat{Y}_{\text {SEKTOR }}=\right.$ Rp. 7.638.507,63 juta, $r_{S E K T O R}=7,08$ persen $)$, dan (3) sektor informasi dan komunikasi $\left(\hat{Y}_{\text {SEKTOR }}=\mathrm{Rp}\right.$. 2.283.688,80 juta, $r_{S E K T O R}=8,78$ persen $)$.

Berdasarkan hasil perhitungan analisis LQ, sektor yang termasuk kedalam sektor basis (LQ>1) yaitu (1) sektor pengadaan listrik dan gas dengan rata-rata nilai LQ sebesar 1,06, (2) sektor pengadaan air, pengolahan sampah limbah dan daur ulang dengan rata-rata nilai LQ sebesar 1,38, (3) sektor konstruksi dengan rata-rata nilai LQ sebesar 1,04, (4) sektor transportasi dan pergudangan dengan rata-rata nilai LQ sebesar 2,42, (5) sektor penyediaan akomodasi dan makan minum dengan rata-rata nilai LQ sebesar 1,30, dan (6) sektor informasi \& komunikasi dengan rata-rata nilai LQ sebesar 1,21.

Tabel 4.

Sektor Unggulan di Kabupaten Badung

\begin{tabular}{lccc}
\hline \multicolumn{1}{c}{ Sektor Unggulan } & \multicolumn{3}{c}{ Hasil Analisis } \\
\cline { 2 - 4 } & Tipologi Klassen & LQ & Overlay \\
\hline Penyediaan Akomodasi dan Makan Minum & Kuadran I & 1,30 & ++ \\
Informasi dan Komunikasi & Kuadran I & 1,21 & ++ \\
\hline Sumber: data diolah, 2018 & & &
\end{tabular}

Dilihat dari tabel 4 sektor penyediaan akomodasi dan makan minum merupakan aktivitas produksi yang menjadi potensi unggulan di Kabupaten 
Badung karena merupakan pusat dari tujuan wisata di Provinsi Bali dimana banyaknya objek wisata yang terdapat di Kabupaten Badung yaitu sebanyak 26 objek, kemudian sarana pendukung kegiatan pariwisata yaitu seperti restoran sebanyak 966 buah, rumah makan sebanyak 513 buah, dan bar sebanyak 370 buah, selain itu usaha akomodasi yang terdapat di Kabupaten Badung yaitu hotel bintang sebanyak 155 buah, hotel melati sebanyak 521 buah, pondok wisata sebanyak 775 buah, kondotel sebanyak 50 buah, rumah sewa sebanyak 40 buah. Banyaknya wisatawan Nusantara yang menginap di akomodasi komersial di Kabupaten Badung pada tahun 2016 sebanyak 877.660 orang meningkat bila dibandingkan dengan tahun sebelumnya sebanyak 462.808 orang (Badung dalam angka, 2017).

Berdasarkan hasil perhitungan dari analisis Tipologi Klassen, LQ dan Overlay sektor penyediaan akomodasi dan makan minum memenuhi katagori sektor unggulan yaitu pada analisis Tipologi Klassen besarnya rata-rata kontribusi sektor terhadap PDRB Kabupaten Badung $\left(\hat{Y}_{\text {SEKTOR }}\right)$ sebesar Rp. 7.638.507,63 juta (Rp. 7.638.507,63 juta > Rp. 1.721.551,45 juta) dan rata-rata laju pertumbuhan sektornya $\left(r_{\text {SEKTOR }}\right)$ sebesar 7,08 persen $(7,08$ persen $>6,78$ persen $)$, sedangkan pada analisis LQ besarnya nilai LQ pada sektor penyediaan akomodasi dan makan minum yaitu $1,30(1,30>1)$ dan pada analisis overlay yang didasari oleh kombinasi dari hasil analisis Tipologi Klassen dan LQ sektor penyediaan akomodasi dan makan minum memiliki dua nilai positif (+).

Sektor unggulan yang kedua yaitu sektor informasi dan komunikasi, dimana sektor ini merupakan salah satu sektor yang berkontribusi cukup besar terhadap 
Putu Indra Perdana Putra, Analisis Sektor Unggulan...

PDRB Kabupaten Badung hal ini terjadi salah satunya karena jumlah pelanggan telepon di Kabupaten Badung tergolong cukup besar. Banyaknya pelanggan telepon pada tahun 2016 yaitu 68.429 pelanggan meningkat bila dibandingkan dengan tahun sebelumnya yaitu sebanyak 59.053 pelanggan (Badung dalam angka, 2017).

Menurut hasil perhitungan dari analisis Tipologi Klassen, LQ dan Overlay sektor informasi dan komunikasi memenuhi katagori sektor unggulan yaitu pada analisis Tipologi Klassen besarnya rata-rata kontribusi sektor terhadap PDRB Kabupaten Badung ( $\hat{Y}_{\text {SEKTOR }}$ ) sebesar Rp. 2.283.688,80 juta (Rp. 2.283.688,80 juta $>$ Rp. 1.721.551,45 juta) dan rata-rata laju pertumbuhan sektornya ( rEEKTOR $)$ sebesar 8,78 persen $(8,78$ persen $>6,78$ persen), sedangkan pada analisis LQ besarnya nilai LQ pada sektor informasi dan komunikasi yaitu 1,21 (1,21 > 1) dan pada analisis overlay yang didasari oleh kombinasi dari hasil analisis Tipologi Klassen dan LQ sektor informasi dan komunikasi memiliki dua nilai positif (+).

Berdasarkan hasil analisis Tipologi Klassen di kabupaten Gianyar, sektor menempati Kuadran I (sektor unggulan) yaitu (1) sektor industri pengolahan $\left(\hat{Y}_{\text {SEKTOR }}=\right.$ Rp. $1.914 .923,71$ juta, $r_{\text {SEKTOR }}=7,24$ persen $),(2)$ sektor perdagangan besar dan eceran $\left(\hat{Y}_{\text {SEKTOR }}=\right.$ Rp. $1.190 .603,78$ juta, $r_{\text {SEKTOR }}=7,55$ persen $)$, (3) sektor penyediaan akomodasi dan makan minum $\left(\hat{Y}_{\text {SEKTOR }}=\right.$ Rp. $3.133 .549,83$ juta, $r_{\text {SEKTOR }}=7,75$ persen $)$, (4) sektor informasi dan komunikasi $\left(\hat{Y}_{\text {SEKTOR }}=\mathrm{Rp}\right.$. 1.147.633,53 juta, $r_{S E K T O R}=8,46$ persen), dan (5) sektor administrasi pemerintah, pertahanan dan jaminan sosial wajib $\left(\hat{Y}_{\text {SEKTOR }}=\right.$ Rp. $916.513,32$ juta, $r_{S E K T O R}=$ 8,55 persen). 
Berdasarkan hasil perhitungan analisis LQ, sektor yang termasuk kedalam sektor basis (LQ>1) yaitu (1) sektor pertambangan dan penggalian dengan ratarata nilai LQ sebesar 1,53, (2) sektor industri pengolahan dengan rata-rata nilai LQ sebesar 1,88, (3) sektor konstruksi dengan rata-rata nilai LQ sebesar 1,23, (4) sektor penyediaan akomodasi dan makan minum dengan rata-rata nilai LQ sebesar 1,03, (5) sektor informasi dan komunikasi dengan rata-rata nilai LQ sebesar 1,17, (6) sektor real estat dengan rata-rata nilai LQ sebesar 1,08, (7) sektor jasa perusahaan dengan rata-rata nilai LQ sebesar 1,08, (8) sektor administrasi pemerintah, pertahanan dan jaminan sosial wajib dengan rata-rata nilai LQ sebesar 1,01, (9) sektor jasa kesehatan dan kegiatan sosial dengan rata-rata nilai LQ sebesar 1,51, dan (10) sektor jasa lainnya dengan rata-rata nilai LQ sebesar 1,12.

Tabel 5.

Sektor Unggulan di Kabupaten Gianyar

\begin{tabular}{lccc}
\hline \multicolumn{1}{c}{ Sektor Unggulan } & \multicolumn{2}{c}{ Hasil Analisis } \\
\cline { 2 - 4 } & Tipologi Klassen & LQ & Overlay \\
\hline Industri Pengolahan & Kuadran I & 1,88 & ++ \\
Penyediaan Akomodasi dan Makan Minum & Kuadran I & 1,03 & ++ \\
Informasi dan Komunikasi & Kuadran I & 1,17 & ++ \\
Adm.Pemerintah, Pertahanan dan Jaminan & Kuadran I & 1,01 & ++ \\
Sosial Wajib & & & \\
\hline Sumber: data diolah, 2018 & &
\end{tabular}

Dilihat dari tabel 5. sektor industri pengolahan merupakan aktivitas produksi yang menjadi potensi unggulan di Kabupaten Gianyar. Berdasarkan data dari Dinas Perindustrian, Perdagangan, dan Koperasi Kabupaten Gianyar tercatat jumlah perusahaan industri besar dan sedang tahun 2016 adalah 59 perusahaan, sedangkan jumlah perusahaan industri kecil tahun 2016 adalah 23.248 perusahaan (Gianyar dalam angka, 2017). 
Putu Indra Perdana Putra, Analisis Sektor Unggulan...

Menurut hasil perhitungan dari analisis Tipologi Klassen, LQ dan Overlay sektor industri pengolahan memenuhi katagori sektor unggulan yaitu pada analisis Tipologi Klassen besarnya rata-rata kontribusi sektor terhadap PDRB Kabupaten Gianyar $\left(\hat{Y}_{\text {SEKTOR }}\right)$ sebesar Rp. 1.914.923,71 juta (Rp. 1.914.923,71 juta > Rp. 893.602,66 juta) dan rata-rata laju pertumbuhan sektornya $\left(r_{S E K T O R}\right)$ sebesar 7,24 persen (7,24 persen $>6,48$ persen), sedangkan pada analisis LQ besarnya nilai LQ pada sektor industri pengolahan yaitu $1,88(1,88>1)$ dan pada analisis overlay yang didasari oleh kombinasi dari hasil analisis Tipologi Klassen dan LQ sektor ini memiliki dua nilai positif $(+)$.

Sektor unggulan yang kedua adalah sektor penyediaan akomodasi dan makan minum. Kabupaten Gianyar merupakan salah satu tujuan wisata di Pulau Bali yang memiliki 62 obyek wisata yang tersebar di tujuh kecamatan di Kabupaten Gianyar. Jumlah kunjungan wisatawan ke obyek wisata di Kabupaten Gianyar pada tahun 2016 adalah 1.065 .322 orang dan mengalami peningkatan dari tahun sebelumnya yaitu sebanyak 923.199 orang. Kabupaten Gianyar memiliki 390 buah tempat akomodasi, dengan rincian 19 buah hotel bintang dan 367 hotel non bintang (Gianyar dalam angka, 2017).

Berdasarkan hasil perhitungan dari analisis Tipologi Klassen, LQ dan Overlay sektor penyediaan akomodasi dan makan minum memenuhi kategori sektor unggulan yaitu pada analisis Tipologi Klassen besarnya rata-rata kontribusi sektor terhadap PDRB Kabupaten Gianyar $\left(\hat{Y}_{\text {SEKTOR }}\right)$ sebesar Rp. 3.133.549,83 juta (Rp. 3.133.549,83 juta > Rp. 893.602,66 juta) dan rata-rata laju pertumbuhan sektornya $\left(r_{\text {SEKTOR }}\right)$ sebesar 7,75 persen $(7,75$ persen $>6,48$ persen $)$, sedangkan 
pada analisis LQ besarnya nilai LQ pada sektor penyediaan akomodasi dan makan minum yaitu $1,03(1,03>1)$ dan pada analisis overlay yang didasari oleh kombinasi dari hasil analisis Tipologi Klassen dan LQ sektor ini memiliki dua nilai positif (+).

Sektor unggulan yang ketiga adalah sektor informasi dan komunikasi. Berdasarkan hasil perhitungan dari analisis Tipologi Klassen, LQ dan Overlay sektor informasi dan komunikasi memenuhi katagori sektor unggulan yaitu pada analisis Tipologi Klassen besarnya rata-rata kontribusi sektor terhadap PDRB Kabupaten Gianyar $\left(\hat{Y}_{\text {SEKTOR }}\right)$ sebesar Rp. 1.147.633,53 juta (Rp. 1.147.633,53 juta $>$ Rp. 893.602,66 juta) dan rata-rata laju pertumbuhan sektornya $\left(r_{S E K T O R}\right)$ sebesar 8,46 persen (8,46 persen > 6,48 persen), sedangkan pada analisis LQ besarnya nilai LQ pada sektor informasi dan komunikasi yaitu 1,17 $(1,17>1)$ dan pada analisis overlay yang didasari oleh kombinasi dari hasil analisis Tipologi Klassen dan LQ sektor ini memiliki dua nilai positif (+).

Sektor unggulan yang keempat yaitu sektor administrasi pemerintah, pertahanan dan jaminan sosial wajib. Berdasarkan hasil perhitungan dari analisis Tipologi Klassen, LQ dan Overlay sektor administrasi pemerintah, pertahanan dan jaminan sosial wajib memenuhi katagori sektor unggulan yaitu pada analisis Tipologi Klassen besarnya rata-rata kontribusi sektor terhadap PDRB Kabupaten Gianyar $\left(\hat{Y}_{\text {SEKTOR }}\right)$ sebesar Rp. 916.513,32 juta (Rp. 916.513,32 juta > Rp. 893.602,66 juta) dan rata-rata laju pertumbuhan sektornya $\left(r_{S E K T O R}\right)$ sebesar 8,55 persen (8,55 persen $>6,48$ persen), sedangkan pada analisis LQ besarnya nilai LQ pada sektor administrasi pemerintah, pertahanan dan jaminan sosial wajib yaitu 
Putu Indra Perdana Putra, Analisis Sektor Unggulan...

$1,01(1,01>1)$ dan pada analisis overlay yang didasari oleh kombinasi dari hasil analisis Tipologi Klassen dan LQ sektor ini memiliki dua nilai positif (+).

Berdasarkan hasil analisis Tipologi Klassen di Kabupaten Tabanan, sektor menempati Kuadran I (sektor unggulan) yaitu (1) sektor industri pengolahan $\left(\hat{Y}_{\text {SEKTOR }}=\right.$ Rp. $758.542,33$ juta, $r_{\text {SEKTOR }}=8,19$ persen $)$, (2) sektor perdagangan besar dan eceran $\left(\hat{Y}_{\text {SEKTOR }}=\right.$ Rp. 1.100.976,24 juta, $r_{\text {SEKTOR }}=8,06$ persen $)$, (3) sektor informasi dan komunikasi $\left(\hat{Y}_{\text {SEKTOR }}=\right.$ Rp. 861.122,94 juta, $r_{S E K T O R}=9,00$ persen), dan (4) sektor administrasi pemerintah, pertahanan dan jaminan sosial wajib $\left(\hat{Y}_{\text {SEKTOR }}=\right.$ Rp. 1.081.461,01 juta, $r_{S E K T O R}=8,57$ persen $)$.

Berdasarkan hasil perhitungan analisis LQ, sektor yang termasuk kedalam sektor basis (LQ>1) yaitu (1) sektor pertanian, kehutanan dan perikanan dengan rata-rata nilai LQ sebesar 1,51, (2) sektor pertambangan dan penggalian dengan rata-rata nilai LQ sebesar 1,10, (3) sektor konstruksi dengan rata-rata nilai LQ sebesar 1,06, (4) sektor informasi dan komunikasi dengan rata-rata nilai LQ sebesar 1,05, (5) sektor real estat dengan rata-rata nilai LQ sebesar 1,23, (6) sektor administrasi pemerintah, pertahanan dan jaminan sosial wajib dengan rata-rata nilai LQ sebesar 1,43, (7) sektor jasa kesehatan dan kegiatan sosial dengan ratarata nilai LQ sebesar 1,09, dan (8) sektor jasa lainnya dengan rata-rata nilai LQ sebesar 1,20 .

Tabel 6.

Sektor Unggulan di Kabupaten Tabanan

\begin{tabular}{lccc}
\hline \multicolumn{1}{c}{ Sektor Unggulan } & \multicolumn{2}{c}{ Hasil Analisis } \\
\cline { 2 - 4 } & Tipologi Klassen & LQ & Overlay \\
\hline Informasi dan Komunikasi & Kuadran I & 1,05 & ++ \\
Adm.Pemerintah, Pertahanan dan Jaminan & Kuadran I & 1,43 & ++ \\
Sosial Wajib & & \\
\hline Sumber: data diolah, 2018 & &
\end{tabular}


Dilihat dari tabel 6 sektor unggulan yang pertama yaitu sektor informasi dan komunikasi. Berdasarkan hasil perhitungan dari analisis Tipologi Klassen, LQ dan Overlay sektor informasi dan komunikasi memenuhi katagori sektor unggulan yaitu pada analisis Tipologi Klassen besarnya rata-rata kontribusi sektor terhadap PDRB Kabupaten Tabanan $\left(\hat{Y}_{\text {SEKTOR }}\right)$ sebesar Rp. 861.122,94 juta (Rp. 861.122,94 juta > Rp. 744.811,09 juta) dan rata-rata laju pertumbuhan sektornya ( $\left.r_{S E K T O R}\right)$ sebesar 9,00 persen $(9,00$ persen $>6,30$ persen $)$, sedangkan pada analisis LQ besarnya nilai LQ pada sektor informasi dan komunikasi yaitu 1,05 (1,05>1) dan pada analisis overlay yang didasari oleh kombinasi dari hasil analisis Tipologi Klassen dan LQ sektor ini memiliki dua nilai positif (+).

Sektor unggulan yang kedua yaitu sektor administrasi pemerintah, pertahanan dan jaminan sosial wajib. Berdasarkan hasil perhitungan dari analisis Tipologi Klassen, LQ dan Overlay sektor administrasi pemerintah, pertahanan dan jaminan sosial wajib memenuhi katagori sektor unggulan yaitu pada analisis Tipologi Klassen besarnya rata-rata kontribusi sektor terhadap PDRB Kabupaten Tabanan $\left(\hat{Y}_{\text {SEKTOR }}\right)$ sebesar Rp. 1.081.461,01 juta (Rp. 1.081.461,01 juta > Rp. 744.811,09 juta) dan rata-rata laju pertumbuhan sektornya ( $r_{\text {SEKTOR }}$ ) sebesar 8,57 persen (8,57 persen $>6,30$ persen), sedangkan pada analisis LQ besarnya nilai LQ pada sektor administrasi pemerintah, pertahanan dan jaminan sosial wajib yaitu 1,43 $(1,43>1)$ dan pada analisis overlay yang didasari oleh kombinasi dari hasil analisis Tipologi Klassen dan LQ sektor ini memiliki dua nilai positif (+). 
Tabel 7.

Sektor Unggulan Perekonomian di Wilayah Sarbagita

Kabupaten/Kota

Sektor Unggulan

\begin{tabular}{|c|c|}
\hline Denpasar & $\begin{array}{l}\text { Perdagangan Besar dan Eceran } \\
\text { Jasa Keuangan dan Asuransi } \\
\text { Jasa Pendidikan }\end{array}$ \\
\hline Badung & $\begin{array}{l}\text { Penyediaan Akomodasi dan Makan Minum } \\
\text { Informasi dan Komunikasi }\end{array}$ \\
\hline Gianyar & $\begin{array}{l}\text { Industri Pengolahan } \\
\text { Penyediaan Akomodasi dan Makan Minum } \\
\text { Informasi \& Komunikasi } \\
\text { Adm.Pemerintah, Pertahanan dan Jaminan Sosial Wajib }\end{array}$ \\
\hline Tabanan & $\begin{array}{l}\text { Informasi dan Komunikasi } \\
\text { Adm.Pemerintah, Pertahanan dan Jaminan Sosial Wajib }\end{array}$ \\
\hline
\end{tabular}

Sumber: data diolah, 2018

Berdasarkan tabel 7 sektor yang menjadi unggulan di wilayah Sarbagita pada periode 2014-2016 yaitu: (1) sektor perdagangan besar dan eceran, (2) sektor jasa keuangan dan asuransi, (3) sektor jasa pendidikan, (4) sektor penyediaan akomodasi dan makan minum, (5) sektor informasi dan komunikasi, (6) sektor industri pengolahan, dan (7) sektor administrasi pemerintahan, pertahanan, dan jaminan sosial wajib.

Implikasi dari hasil pemetaan mengenai sektor-sektor unggulan yang terdapat di kabupaten/kota di wilayah Sarbagita terhadap kebijakan manajemen keuangan publik menurut Mahmudi (2009:49) adalah untuk sektor-sektor perekonomian yang menjadi sektor unggulan, pemerintah daerah di kabupaten/kota masing-masing harus menjaga stabilitas pertumbuhan dari sektorsektor unggulan tersebut, karena sektor-sektor unggulan tersebut merupakan kekuatan dan daya saing daerah dalam meningkatkan perekonomian daerah. Jika pengelolaan sektor-sektor unggulan tersebut tidak dilakukan dengan baik maka sektor tersebut akan terancam bergeser menjadi sektor potensial, yakni pertumbuhan sektor tersebut mengalami penurunan walaupun kontribusinya 
terhadap PDRB tergolong besar. Rencana kedepan untuk pengelolaan sektor unggulan pada masing-masing kabupaten/kota di wilayah Sarbagita adalah dengan melakukan pengembangan, promosi, dan ekspansi.

\section{SIMPULAN DAN SARAN}

Penelitian ini memiliki keterbatasan dalam menganalisis sektor unggulan perekonomian daerah berdasarkan sektor, karena subsektor dari masing-masing komoditi sektor tidak dapat diketahui dengan jelas yang menjadi sektor unggulan daerah tersebut. Perhitungan subsektor tersebut dapat digunakan untuk memperkuat interpretasi atau pembahasan dari hasil penelitian. Berdasarkan keterbatasan penelitian tersebut disarankan bagi peneliti selanjutnya untuk menganalisis sektor unggulan perekonomian daerah dengan menggunakan subsektor dari komoditi masing-masing sektor yang terdapat dalam PDRB.

Saran yang dapat diberikan berdasarkan kesimpulan yang diperoleh adalah bagi peneliti selanjutnya diharapkan untuk menganalisis sektor unggulan perekonomian daerah dengan menggunakan subsektor dari sektor yang terdapat dalam PDRB. Bagi pemerintah daerah di wilayah Sarbagita diharapkan mampu mengelola secara optimal sektor yang menjadi unggulan tanpa mengabaikan sektor lainnya dalam perencanaan dan pelaksanaan pembangunan.

\section{REFERENSI}

Almulaibari, Hilal. 2011. Analisis Potensi Pertumbuhan Ekonomi Kota Tegal Tahun 2004-2008. Skripsi publikasi, Fakultas Ekonomi Universitas Diponegoro, Semarang.

Arsyad, Lincolin. 2015. Ekonomi Pembangunan. Edisi Ke 5. Yogyakarta: UPP STIM YKPN. 
Putu Indra Perdana Putra, Analisis Sektor Unggulan...

Aryanti, Eni dan Iin Indarti. 2009. Pengaruh Variabel Makro Terhadap Pendapatan Asli Daerah Periode 2000-2009 di Kota Semarang. Jurnal Sekolah Tinggi Ilmu Eko Widya Manggela.

Aswandi, H, dan Kuncoro, M, 2002, Evaluasi Penetapan Kawasan Andalan: Struktur Empiris di Kalimantan Selatan 1993-1999. Jurnal Ekonomi dan Bisnis Indonesia, 17 (1), hal.27-45.

Ayu, Fajar Nur dan Wiagustini. Potensi Ekonomi Daerah Provinsi Bali. E-Jurnal Manajemen Unud, 5 (12), hal.7528-7554.

Barro, Robert J. 1991. Economic Growth in A Cross Section of Countries. The Quarterly Journal of Economics, 106 (2), pp.407-433.

Badan Pusat Statistik. 2017. Kabupaten Badung Dalam Angka 2017. http://badungkab.bps.go.id. Diakses 4 Oktober 2017.

Badan Pusat Statistik. 2017. Kabupaten Gianyar Dalam Angka 2017. http://gianyarkab.bps.go.id. Diakses 4 Oktober 2017.

Badan Pusat Statistik 2017. Kabupaten Tabanan Dalam Angka 2017. http://tabanankab.bps.go.id. Diakses 4 Oktober 2017.

Badan Pusat Statistik 2017. Kota Denpasar Dalam Angka 2017. http://denpasarkota.bps.go.id. Diakses 4 Oktober 2017.

Badan Pusat Statistik 2017. Provinsi Bali Dalam Angka 2017. http://bali.bps.go.id. Diakses 4 Oktober 2017.

Carlin, Wendy and Colin Mayer. 2003. Finance, Investment and Growth. Journal of Financial Economics, 69 (1), pp.191-226.

Dearlinasinaga. 2015. Determination Analysis of Leading Economic Sector Against Forming Region GDP in Simalungun. International Journal of Innovative Research in Management, 4 (3), pp.1-12.

Erawati, dan Mahaendra Yasa. 2012. Analisis Pola Pertumbuhan Ekonomi dan Sektor Potensial Kabupaten Klungkung. E-Jurnal Ekonomi Pembangunan Universitas Udayana, 1 (1), hal.41-61.

Erawati, Ni Made Adi. 2012. Analisis Kinerja Kawasan Metropolitan Sarbagita. Jurnal Ilmiah Akuntansi dan Bisnis, Universitas Udayana, 7 (1), hal.1-19.

Gitaningtyas, Yeny Kurniawati dan Taufik Kurrohman. 2014. Pengaruh Produk Domestik Regional Bruto, Jumlah Penduduk, dan Investasi Swasta Terhadap Realisasi Pendapatan Asli Daerah Pada Kabupaten/Kota di Provinsi Jawa Timur. Artikel Ilmiah Mahasiswa Universitas Jember. 
Gustiana, Andi. 2014. Pendapatan Asli Daerah, Dana Alokasi Umum dan Belanja Modal Terhadap Pertumbuhan Ekonomi. Skripsi publikasi, Fakultas Ekonomi dan Bisnis, Universitas Hasanuddin.

Haris, Zulfi. 2012. Analisis Penentuan Sektor/Subsektor Unggulan dan Kaitannya dengan Perencanaan Pembangunan Ekonomi Kabupaten Lampung Utara. Tesis publikasi. Fakultas Ekonomi Universitas Indonesia.

Hendayana, Rachmat. 2003. Aplikasi Metode Location Quotient (LQ) dalam Penentuan Komoditas Unggulan Nasional. Informatika Pertanian. 12 (1), hal.1-21

Hermanto. 2000. Analisis Spasial Regional Provinsi Kalimantan Tengah. JESP UII. 1 (1), hal.45-72.

Isserman, Andrew M. 1997. The Location Quotient Approach to Estimating Regional Economic Impacts. Journal of the American Planning Association. 43 (1), pp.33-41

Kesuma, dan Suyana Utama, 2015, Analisis Sektor Unggulan dan Pergeseran Pangsa Sektor - Sektor Ekonomi Kabupaten Klungkung. Jurnal Ekonomi Kuantitatif Terapan. 8 (1), hal.2015.

Mack, Richard S. and David S. Jacobson. 1996. Core Periphery Analysis of The European Uniaon: A Location Quotient Approach. The Journal of Regional Analysis \& Policy, 26 (1), pp.3-21.

Mahmudi. 2009. Manajemen KeuanganDaerah. Jakarta: Erlangga.

Miller, M.M \& Wright. 1991. Location Quotient Basic Tool for Economic Development Analysis. Economic Development Review, 9 (2), pp.65.

Olatunji, O.C., O. Asaolu Taiwo and J.O. Adewoye. 2009. A Riview of Revenue Generation in Nigeria Local Government: A Case Study of Ekiti State. Medwell Journal International Business Management, 3 (3), pp.54-60.

Peraturan Presiden Republik Indonesia Nomor 45 Tahun 2011 tentang Rencana Tata Ruang Kawasan Perkotaan Denpasar, Badung, Gianyar, dan Tabanan.

Peraturan Presiden Republik Indonesia Nomor 51 Tahun 2014 tentang Perubahan Atas Peraturan Presiden Nomor 45 Tahun 2011 tentang Rencana Tata Ruang Kawasan Perkotaan Denpasar, Badung, Gianyar, dan Tabanan.

Prishardoyo, Bambang. 2008. Analisis Tingkat Pertumbuhan Ekonomi dan Potensi Ekonomi Terhadap Produk Domestik Rehional Bruto (PDRB) Kabupaten Pati Tahun 2000-2005. Jurnal Ekonomi dan Kebijakan, 1 (1), hal.1-8. 
Putu Indra Perdana Putra, Analisis Sektor Unggulan...

Puspitawati, Linda Tustiana. 2013. Analisis Perbandingan Faktor-Faktor Penyebab Ketimpangan Pembangunan Antar Kabupaten/Kota di Kawasan Kedungsapur. Economics Development Analysis Journal, 2 (2), hal.1-16.

Ratnasari, Emma Dwi. 2014. Sector Analysis and Determinan of GDP Forming Leading Sector in District Kebumen. Jurnal Fokus Bisnis, 13 (1), pp.1-29.

Rini, Setio. 2006. Analisis Pertumbuhan Sektor - Sektor Perekonomian 30 Provinsi di Indonesia Tahun 1998 dan 2003. Skripsi publikasi. Fakultas Ekonomi dan Manajemen Departemen Ilmu Ekonomi, Institut Pertanian Bogor.

Ron Hood, 1998. Economic Analysis: A Location Quotient. Primer. Principal Sun Region Associates, Inc.

Sabar, Wardihan. 2015. Sektor Potensial Pengembangan Ekonomi Wilayah. EJournal Universitas Islam Negeri Alauddin Makassar. 2 (1), hal.48-61.

Sudewi, Ni Nyoman Ayu dan Wirathi, I.G.A.P. 2013. Pengaruh Desentralisasi Fiskal dan Pertumbuhan Ekonomi Terhadap Kemiskinan Provinsi Bali. EJurnal EP Unud, 2 (3), hal.135-141.

Susanto, Dimas Aditiya. 2013. Analisis Potensi Ekonomi Sub Sektor Industri Pengolahan Kota Tanggerang Periode 2005 - 2010. Skripsi publikasi, Fakultas Ekonomi Jurusan Ilmu Ekonomi Dan Studi Pembangunan, Universitas Islam Negeri Jakarta.

Susiani. 2012. Analisis Penentuan Sektor Potensial di Kabupaten Badung Berdasarkan Produk Domestik Regional Bruto 2001-2010. Skripsi tidak dipublikasi, Program Ekstensi Fakultas Ekonomi dan Bisnis, Universitas Udayana.

Uhunmwuangho, S.O. and Stanley Aibieyi. 2013. Problems of Revenue Generation in Local Government Administration in Nigeria. An International Journal of Arts and Humanities Bahir Dar, Ethiophia, 2 (3), pp.192-209

UU No. 32 Tahun 2004 tentang Pemerintahan Daerah

UU No. 33 Tahun 2004 tentang Perimbangan Keuangan antara Pemerintah Pusat dan Pemerintahan Daerah

Wulandari, Pande Paramitha dan Ayuningsasi. 2014. Analisis Variabel-Variabel yang Mempengaruhi Pendapatan Asli Daerah Provinsi Bali. E-Jurnal Ekonomi Pembangunan Universitas Udayana, 3 (11), hal.530-539. 
E-Jurnal Manajemen Unud, Vol. 7, No. 10, 2018: 5657-5685

Yusral, Junaidi, dan Adi Bakti. 2015. Klasifikasi Pertumbuhan, Sektor Basis dan Kompetitif Kota Jambi. Jurnal Perspektif Pembiayaan dan Pembangunan Daerah, 2 (4), hal.209-216. 